\title{
THE OXFORD CLAY: A PALEONTOLOGICAL LABORATORY
}

\author{
HUDSON, JOHN D., Dept. of Geology, University of Leicester, \\ Leicester \\ LE $17 \mathrm{RH}$, U.K.
}

The Lower Oxford Clay, a marine formation of Middle Jurassic (Callovian) age exposed in central and southern England, merits the attention of paleontologists and geochemists for several reasons. It was the subject of a classic of biostratigraphic and evolutionary paleontology by Brinkmann on the ammonites; sexual dimorphism and bioprovinciality in the same group has since been intensively studied by Callomon and others. Its exploitation by the brick industry has enabled the assembly of one of the most extensive collections of marine vertebrates by the Leeds brothers and later workers; these include the world's largest ever fish, and superbly preserved ichthyosaurs, plesiosaurs and crocodiles now dispersed to museums throughout Europe and beyond. Dinosaurs, while rare, are also diverse. The benthic fauna is dominated by abundant but not diverse molluscs, believed tolerant of soupy bottom conditions and periodic dysoxia. Coccoliths and dinoflagellates represent the phytoplankton. Aragonite, calcite and phosphate biominerals are excellently preserved. In our main study area burial did not exceed $500 \mathrm{~m}$.; organic matter is immature. Early diagenesis resulted in the formation of carbonate concretions that preserve original sediment fabrics elsewhere destroyed by compaction; later diagenesis brought about further mineralogical changes.

Work since the 1970's has resulted in much improved understanding of the Lower Oxford Clay biota and its trophic relationships. It is useful to compare it to the more calcareous Middle and Upper Oxford Clay. The biostratigraphy is extremely well-known. The well-preserved fossils invite microstructural and geochemical studies. Economic concerns add impetus to the study of actual or potential hydrocarbon source rocks. Yet the Lower Oxford Clay is full of enigmas and questions still. It looks quiet-water but has many diastems, not all recognizable by classic criteria like shell beds. The fossil preservation might imply a high sediment delivery rate, but the sediment accumulation rate is low. It is organic-rich, but not anoxic. Where did the enigmatic 'pendent' bivalves live? Whence the nutrients to support the rich biota? To what extent do organic compounds survive from the primary producers, or does heterotrophic reworking dominate? Can we refine or quantify trophic relationships? We should also be able to use our 'laboratory' for experiments of wider significance for paleotemperatures or paleo- $\mathrm{CO}_{2}$ levels.

In the Oxford Clay group of papers we attempt to summarize where traditional paleoecological analysis has led us to so far, and to show how the new approaches made possible by advances in isotopic and biomolecular paleontology can revise and refine our ideas, solve old problems and, no doubt, raise new ones. We believe our collaborative approach has much to offer for paleontologists and geochemists, as also exemplified by the other contributions to the symposium. 